\title{
Education and Community in the Rural Midwest: A Review Essay
}

\author{
THOMAS K. DEAN
}

Call School: Rural Education in the Midwest to 1918, by Paul Theobald! Carbondale and Edwardsville: Southern Illinois University Press, 1995. xii, $247 \mathrm{pp}$. Notes, index. $\$ 29.95$ cloth.

Teaching the Commons: Place, Pride, and the Renewal of Community, by Paul Theobald. Boulder, CO: Westview Press/HarperCollins, 1997. ix, 182 pp. Notes, index. $\$ 22.00$ paper.

Paul Theobald, currently dean of education at Wayne State College in Wayne, Nebraska, is earning a reputation as a major voice in the call for place-based education and the reform of rural schools. These two books show his prowess as a general and educational historian, as well as a visionary educational philosopher. With personal history and professional practice grounded in the Midwest, Theobald shows readers how crucial the Midwest has been to the historical development of educational theory and practice in this country, as well as the critical needs of the rural communities in the nation's "breadbasket."

While its ostensible purpose is not school reform, Call School (a phrase that refers to the act of "calling school" into session) focuses on the relationships between education and community character. One of the most valuable aspects of the book is its unwavering effort to cut through the stereotypes and romanticism often applied to the historical and contemporary rural Midwest. Quoting and summarizing mainstream historians of

THE ANNALS OF IOWA 58 (Fall 1999). (CThe State Historical Society of Iowa, 1999. 
midwestern education, Theobald pokes holes in their conclusions. Those conclusions have, unfortunately, become critical assumptions: that rural midwesterners, in their resistance to the development of the common school (a community institution for the education of a locality's children in common, which would lead to public education), were either backward ignoramuses or, as more contemporary historians would have it, yeoman farmers who stood up to the evils of centralization and urbanization in order to preserve democratic principles and practices in localized rural areas.

Theobald finds both of these theories inadequate. He centers his argument instead on the "religious dimensions underlying both pro- and anti-common school agenda" (31). The architecture of this religious argument rests on popping a couple of other stereotypical balloons as well. It is tempting to characterize midwestern agriculture as continuing the Jeffersonian tradition of the yeoman farmer, with rural life based on principles of community and democracy. Theobald, on the other hand, artfully argues that the quick rise of midwestern rural life was based not on transferring Jeffersonian ideals from the corrupt East to the pure West, but rather on unadulterated material acquisition. In other words, folks came to the Midwest to grab land and make a buck off of it. Second, Theobald points out that, in the swift movements westward, with people always looking for the next agricultural gold mine and with land barons grabbing up as much property as they could, midwestern populations, far from being stable, home- and community-oriented "salt of the earth," were in fact extremely transient.

Into this unstable, even exploitative, environment, those with specific religious agendas had ample opportunity to experiment with education. Among the most powerful were those of a Calvinist bent, intent on preserving Puritan traditions. In the rural Midwest, however, the populations were hardly homogeneous. Theobald points out that, contrary to the popular myth, there was hardly universal agreement in the Midwest as to whether or not common schools were even necessary. Those communities that did want schools often found themselves in the midst of battles among denominations for curricular and physical control of rural schools. Much of the resistance to a 
central, common school authority was not on democratic terms, but rather on religious grounds, since the eastern Puritan traditionalists attempted to assert their power, and their ideology, by infiltrating whatever central administrative organizations there may have been in states and territories.

This religious struggle was particularly characteristic of the antebellum Midwest. As the nineteenth century waned, the struggles focused more and more on resistance to "progressive" reforms that valorized an urban, industrial culture that could attract rural students away from farm life. If farm parents had educational goals for their children, they wanted them to learn enough skills to become productive farm workers and solid community members. Even in the postbellum years, however, particularly in the trans-Mississippi Midwest, populations were still quite transient, leading to a system of "community gatekeepers," as Theobald calls them, a minority of landholders who gained control over local education and developed it according to their own interests-hardly a "democratic" system.

Theobald concludes his history with the Country Life Commission of the early twentieth century. Here again, he turns accepted wisdom on its head. Historical tradition has it that rural midwesterners resisted the movement because its goal, through curricular reform and consolidation, was to urbanize rural schools. Theobald argues that, actually, the movement's goals were exactly the opposite: Country Lifers (the majority of the commissioners were originally midwestern rural folk, not urbanites) were intent on stopping rural migration to the cities and "perpetuating existing rural values in the face of rising industrialization" (168) through a holistic experiential curriculum that would make rural children love their communities and rural countryside. Despite their seemingly common goals, farmers resisted the Country Life movement not on ideological grounds so much as practical ones: they were suspicious of "fancy" theories that seemed to them to divert attention from "the basics," and they wanted to maintain "community gatekeeper" control over the schools in resistance to consolidation. Consolidation was, in fact, a Country Life tenet, too, though with the goal of strengthening community, not promoting urbanization. 
Theobald supports his arguments through copious research, presenting innumerable specific examples from journals, diaries, and printed accounts of the time. The strength of his thesis lies in the specific evidence rather than accepted historical dogma. The argument flags a bit in the last two chapters, however. The penultimate chapter, "Recess, Recitation, and the Switch: Students and Teachers in Midwest Country Schools," is a delightful peek into everyday nineteenth-century schoolroom life, including numerous examples from Iowa, yet it seems to lack a strong connection to the overall argument of the book. Within that chapter, unlike through the rest of the book, where regional and local differences are discussed clearly, Theobald also draws on examples from numerous localities to make a general observation about "rural school life," as if that were the same in Indiana and North Dakota. The final chapter on the Country Life Commission continues to make its points, but it lacks the clarity and conviction of argument, as well as the copious specific support, of the earlier chapters. On the whole, however, Call School is a provocative, well-argued, and essential history of education in the Midwest that helps us understand the region without the cloudy lenses of nostalgia and assumption.

Theobald's most recent book, Teaching the Commons, follows through on his themes of education and rural and community life differently. On the surface, it appears that the major thrust of the book will be educational theory and practice, but readers going into the book with that assumption may be a bit disappointed. Only the last section, "Education and the Renewal of Community," which constitutes about 25 percent of the book, focuses on what specifically needs to be done and could be done in our classrooms. In that section, Theobald takes a narrative approach, spinning a tale of a couple of hypothetical teachers who focus on inquiry-based, hands-on, community-based teaching, and the challenges and successes involved. That makes for interesting reading, but the argument could have been more convincing with more concrete, real-life examples. But I did leave that section wanting much more, which speaks very well for what is provided.

The strength of the last section is its visionary quality. Theobald leads up to it by grounding his vision in a perceptive and 
radical interpretation of history. As in Call School, he is fearless in his efforts to poke holes in common wisdom and to challenge sacred cows. The bulk of the book is given over to a deep look at how western culture-starting from the ancient Greeks and moving up to the present day-has abandoned a communal way of life for an individualistic, corporate, economic, propertyoriented, acquisitive, mass approach. The result of the modern view of life-which, in contemporary America, defines everything that is well and good-is the elimination of the common good and sustainable living, the dispossession of people from their relationship with the land, particularly in the countryside. In Theobald's telling, traditional historical "heroes" such as St. Augustine and Alexander Hamilton become architects of rural and community devastation, and forgotten figures such as Gerrard Winstanley and Daniel Shays rise to our consciousness as champions of sustainable rural communal life. It is this kind of historical archeology, presented from a long-suppressed perspective, that makes Teaching the Commons invaluable.

Theobald challenges not only mainstream historical understanding in the book, but also accepted wisdom about what makes for a successful culture, person, and school. He focuses on many unquestioned goals in contemporary society and education-"ownership" of ideas and risk-taking, for exampleand shows their destructive sides. For Theobald, feudal life, with its cyclic time and its avoidance of risk in favor of preserving a known, sustainable relationship with land and community, is not backward, but rather the ideal of sustainable living. These are challenging concepts that run counter to the existing educational environment, but the challenge promotes an ongoing relationship with the book. I embrace Theobald's conclusions about where our culture and our educational systems are, and I embrace his solutions enthusiastically. At the same time, those solutions entail certain values and ideas that go against my grain.

The fundamental idea of the book, however, is one that anyone who wishes for more community- and place-oriented education would accept readily. Theobald's greatest contribution, perhaps, is framing his argument with the idea of intradependence. Moving beyond the idea of interdependence, which in- 
volves reciprocal relations among people, intradependence means "to exist by virtue of necessary relations within a place" (7). It is this crucial element of place that is missing from our educational theory and practice today, and it is the element most necessary for the renewal of community.

Teaching the Commons does not speak specifically to midwestern history, life, or education, but it is an important companion piece to Call School. Between these two books, one can glean an important, original understanding of the history of education in the Midwest, buttressed by an understanding of how midwestern culture got where it is through larger developments in the history of the western world. Such historical understanding is made perilously necessary by a vision of where rural and place-oriented education needs to go in the future in order to preserve and enhance midwestern as well as national education and community life. 
Copyright of Annals of Iowa is the property of State of Iowa, by \& through the State Historical Society of Iowa and its content may not be copied or emailed to multiple sites or posted to a listserv without the copyright holder's express written permission. However, users may print, download, or email articles for individual use. 